\title{
Hemoptysis - a sign of primary cardiac malignancy
}

\author{
Mader, C ; Stolzmann, P ; Leschka, S ; Alkadhi, H ; Scheffel, H
}

Abstract: Image of the month

DOI: https://doi.org/10.1007/s00059-010-3357-8

Posted at the Zurich Open Repository and Archive, University of Zurich ZORA URL: https://doi.org/10.5167/uzh-36114

Journal Article

Published Version

Originally published at:

Mader, C; Stolzmann, P; Leschka, S; Alkadhi, H; Scheffel, H (2010). Hemoptysis - a sign of primary cardiac malignancy. Herz, 35(5):355-357.

DOI: https://doi.org/10.1007/s00059-010-3357-8 
Herz 2010 - 35:355-357

DOI 10.1007/s00059-010-3357-8

Received: 3 May 2010

Accepted: 11 June 2010

Published online: 7 July 2010

(c) Urban \& Vogel 2010

C. Mader ${ }^{1}$ P. Stolzmann ${ }^{1,2}$ - S. Leschka ${ }^{3} \cdot$ H. Alkadhi ${ }^{1,2}$ - Hans Scheffel ${ }^{1,2}$

${ }^{1}$ Institute of Diagnostic and Interventional Radiology, University Hospital Zurich, Zurich

${ }^{2}$ Cardiac MR PET CT Program, Massachusetts General

Hospital and Harvard Medical School, Boston

${ }^{3}$ Institute of Radiology, Canton Hospital St. Gallen, St. Gallen

\section{Hemoptysis - \\ a sign of primary \\ cardiac malignancy}

elevated lactate dehydrogenase $(711 \mathrm{U} / \mathrm{L})$ and CRP ( $33 \mathrm{ng} / \mathrm{L})$.

Electrocardiography-gated computed tomography of the chest revealed multiple disseminated pulmonary nodules in both lungs (- Fig. 1a). Additionally, a hypodense intrapericardial mass was detected of approximately $7 \times 5 \mathrm{~cm}^{2}$ in axial size, showing broad-based attachment to the right atrium and ventricle ( $\bullet$ Fig. 1b), and encasement of the right coronary artery (• Fig. 1c). Thereupon, cardiac magnetic resonance imaging (MRI) was performed which showed strong gadolinium uptake of the tumor, as well as infiltration of the right atrial and ventricular wall with nodular thickening of the pericardium (• Fig. 1d). Thoracoscopic wedge resecunremarkable. Laboratory data showed

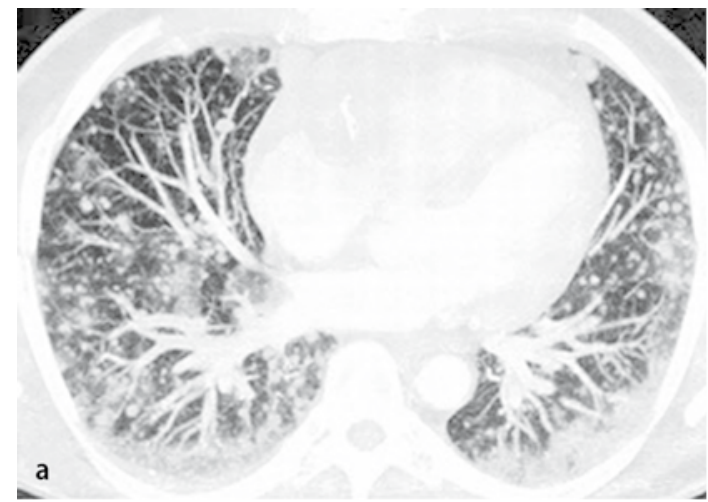

Fig. $1>\mathbf{a}$ CT of the chest depicting multiple pulmonary nodules consistent with lung metastases. b,c The CT revealed a cardiac mass suspicious of primary cardiac angiosarcoma (asterisk) with broad-based attachment to the anterior right atrial and right ventricular wall with encasement of the right coronary artery (arrow). d T1-weighted cardiac MRI demonstrated the tumor (asterisk) with gadolinium enhancement and infiltration of the right ventricle (arrow)

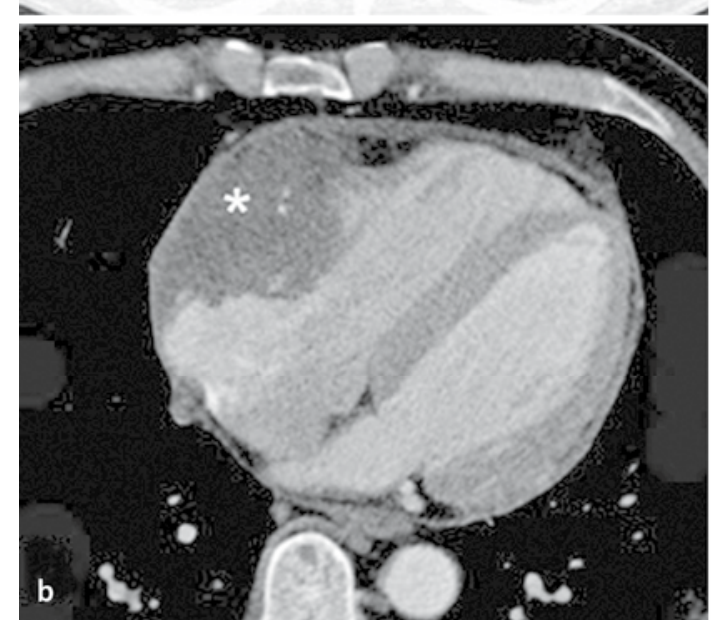

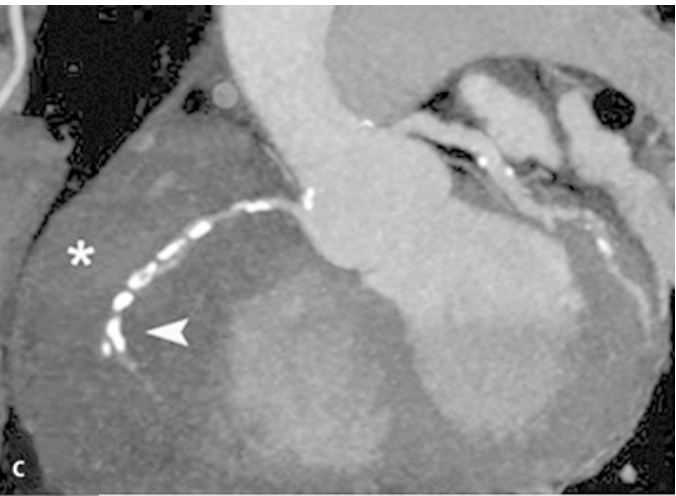

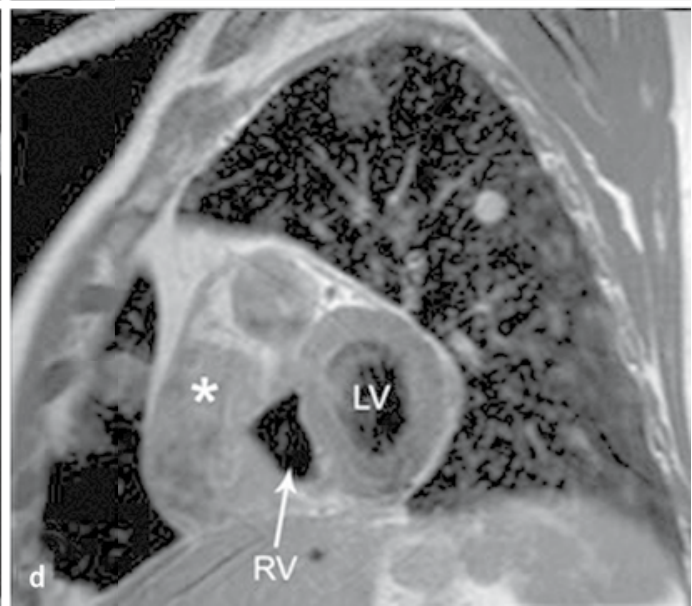


tion of the left upper lobe was performed for diagnostic purposes. Histopathological and immunohistochemical analysis revealed a primary cardiac angiosarcoma with pulmonary metastases. Due to the advanced stage of disease and non-resectability of the primary tumor, chemotherapy was initiated.

Angiosarcoma is the most common primary cardiac malignancy accounting for $33 \%$ of all primary cardiac tumors [ 1 , 2]. The symptoms are commonly unspecific and may range from arrhythmia to right-sided heart failure due to pericardial tamponade. Hemoptysis caused by pulmonary metastases as the leading symptom is rare and should prompt the consideration of primary cardiac malignancy as a differential diagnosis.

\section{Corresponding address}

\section{Hans Scheffel, MD}

Cardiac MR PET CT Program, Massachusetts

General Hospital and Harvard Medical School

100 Charles River Plaza, 02114 Boston

US

hscheffel@partners.org

\section{References}

1. Burke A, Jeudy J Jr, Virmani RM (2008) Cardiac tumours: an update. Heart 94:117-123

2. Maksimović R, Dill T, Seferović PM et al (2006) Magnetic resonance imaging in pericardial diseases. Indications and diagnostic value. Herz 31(7):708-714
Barmeyer, Jürgen

Das kardiologische Gutachten

Anleitungen zur differenzierten

Begutachtung bei Herz-Kreislauf-

Erkrankungen

Stuttgart : Thieme 2010, 2.,

(ISBN 978-3-13-113942-9)

Vor gut 10 Jahren erschien die erste Auflage des Buches „Das kardiologische Gutachten“. Seitdem haben sich in der Kardiologie ein erheblicher Wissenszuwachs und in den Sozialversicherungssystemen bedeutsame Veränderungen ergeben. Insofern war es sinnvoll, eine völlig überarbeitete neue Auflage des Buches vorzulegen. Neu bearbeitet sind insbesondere die Begutachtung in der privaten Berufsunfähigkeitsversicherung und der Pflegeversicherung sowie Aspekte der beruflichen Wiedereingliederung. Das Buch ist aufgeteilt in einen kurzen allgemeinen Teil, in dem insbesondere die Rechtsordnung und ihre Bedeutung für die kardiologische Begutachtung, arbeitsmedizinische Aspekte sowie die gängigen Funktionsprüfungen des Herzens dargestellt sind. Im speziellen Teil werden sodann alle relevanten kardiologischen Erkrankungen, traumatische Herzschädigungen, der Zustand nach Organtransplantation und psychovegetativ bedingte Herz-Kreislauf-Störungen kapitelweise abgehandelt, wobei jeweils die Bemessung von $\mathrm{MdE}$ und $\mathrm{GdB}$ sowie die gutachterliche Beurteilung (unter Berücksichtigung von Unfallversicherung, Rentenversicherung, Entschädigungsrecht, Schwerbehindertenrecht, private Berufsunfähigkeitsversicherung und Pflegeversicherung) angeschlossen werden. Nicht berücksichtigt sind alle strafrechtlichen Aspekte (u.a. Behandlungsfehler, Verwahrfähigkeit, Verhandlungsfähigkeit) und die Verkehrseignungsbeurteilung gemäß Fahrerlaubnisverordnung.

Das Buch ist umfassend und vollständig im Hinblick auf die zivilrechtlichen Aspekte sowie besonders praxistauglich durch die klare Orientierung nach Krankheitsbildern und durch anschauliche Beispiele, welche eine Begutachtung zielführend untermalen. Hieraus ergibt sich dann auch ein hohes Maß an Sicherheit im schwierigen Feld der kardiologischen Begutachtung.

K. Püschel (Hamburg) 
Hier steht eine Anzeige.

算 Springer 